\title{
Assessment of Postural Discomfort among Female Sewing Machine Operators
}

\author{
Neha Gahlot ${ }^{*}$, Manju Mehta and Kiran Singh
}

Dept. of Family Resource Management, C.C.S. Haryana Agricultural University, Hisar, Haryana (125 004), India

Article History

Manuscript No. AR1387a

Received in $12^{\text {th }}$ June, 2015

Received in revised form $24^{\text {th }}$ January, 2016

Accepted in final form $5^{\text {th }}$ February, 2016

\section{Correspondence to}

"E-mail: nehagahlot25@gmail.com

\section{Keywords}

Forward inclined posture, deviation, physically fit, discomfort, RULA

\begin{abstract}
Today women are called upon to undertake the dual role of looking after the family and its needs and also earn for the families maintenance, by taking up either full or part time work for wages. In the process of economic development, women's role has been a major component. The sewing operation is characterized by a static sitting posture, a forward inclined posture of the head and trunk, and relatively uncomfortable ankle and knee angles. The sewing task includes simultaneous hand and arm movements, and the continuous operation of foot pedals. Poor posture of the trunk, neck and upper extremities, and the monotonous repetitive movements result in a high prevalence of musculoskeletal complaints affecting the backs, necks, upper and lower extremities among sewing machine operators. The study was carried out with the objective to assess the postural discomfort of the hand operated female sewing machine operators who work at their home. The physically fit respondents were selected for the study. A record sheet was developed for record the angle of deviation of cervical and lumbar region taken with flexi curve. Rapid upper limb assessment method (RULA) was used to identify the upper limb disorders of female sewing machine operators. The results of the study showed that the respondents were facing postural discomfort while working, so the study suggested to correct the posture and reduce the angle of deviation during sewing activity.
\end{abstract}

\section{Introduction}

Work-related musculoskeletal disorders (WMSD's) have emerged as a major health problem among workers in the developing countries. Working at the ground level with a high degree of flexed posture clearly constitutes a health risk for the musculoskeletal system (Kim and Chung, 1995). Work related musculoskeletal disorders (WMSD's) by definition are a subset of musculoskeletal disorders that arise out of occupational exposures. WMSD's are a group of painful disorders of muscles, tendons, and nerves. Workers in the garment industry have higher rates of upper extremity work-related musculoskeletal disorders than those in many other industries (Herbert et al., 2006). The sewing operation is characterized by a static sitting posture, a forward inclined posture of the head and trunk, and relatively uncomfortable ankle and knee angles. Sewing machine operators performs monotonous and high speed precision task that require sustained non neutral joint posture and highly repetitive movements. The workers usually sits and work in same position for a long period of time (5-6 hours) in nonadjustable work station furniture, creating a sustained load on neck and shoulder muscles. These workers can experience pain that is serving enough to interfere with one or more of their daily activities which lead the work related musculoskeletal problems WMSD's among sewing machine operators due to the sewing task. Pain is the most common symptom associated with WMSD's. Therefore, considering the above-mentioned facts, field experiments were undertaken to study the postural discomfort among the female sewing machine operators.

\section{Materials and Methods}

The present study was conducted for one year (March 2012-Februray 2013) in Hisar city of Hisar district of Haryana state, purposively due to the easy accessibility of researcher and availability of large number of female workers engaged in sewing activity for pecuniary benefits. A sample of 15 sewing machine operators was selected purposively out of 80 female respondents surveyed. Those women, who were physically fit and engaged in sewing activity from the at least 4 years using hand operated sewing machine and were willing to cooperate were selected. In order to avoid any experimental error and to maintain the uniformity in data, only those women were 
selected for the experimental study that had high average to good health status. Physical fitness of the sewing machine operators was ascertained by measuring the four physiological parameters i.e. blood pressure, body temperature, pulse rate and $\mathrm{VO}_{2}$ max.

\subsection{Postural discomfort}

Postural discomfort results when there is change in normal posture. The postural discomfort was assessed through following scales and tools.

\subsection{Flexi curve}

It was used to measure the angle of deviation (degree) between the normal spine curve and maximum deviated posture. The flexi curve was mounted to the contour of the spine and immediately drawn on a plain paper to measure the angle of deviation. The angle of bent of the back during the performance was measured and compared with the normal bent of the back and the angle of deviation was determined by subtracting the normal angle of bent from the angle of bent during the bending posture i.e., while performing sewing activity.

Required angle $=\mathrm{x}$

Measured angle $=\mathrm{y}$

Required angle $(\mathrm{x})=360-\mathrm{y}$

\subsection{RULA}

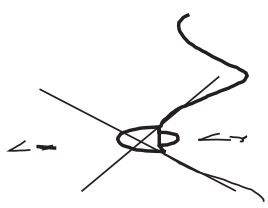

RULA stands for Rapid upper limb assessment method given by Atamney and Corlett, 1993. It is a survey method developed for ergonomics investigations of workplaces where work related upper limb disorders are reported. It uses the diagram of body posture including movement of arms, wrist, neck, trunk and legs by scoring method including three scoring table to evaluate the level of exposure of risk factors. A coding system is used to generate an action list which indicates the level of interventions required to reduce the risk of injury due to physical loading on the operator.

\subsubsection{RULA action sheet}

\begin{tabular}{lrl}
\hline $\begin{array}{l}\text { Action } \\
\text { Level }\end{array}$ & Score & Interpretation \\
\hline 1. & $1-2$ & $\begin{array}{l}\text { Posture is acceptable if it is not maintained } \\
\text { or repeated for long time } \\
\text { Further investigation is needed and change } \\
\text { may be required }\end{array}$ \\
3. & $3-4$ & $\begin{array}{l}\text { Investigation and changes are required } \\
\text { soon } \\
\text { Investigation and changes are required } \\
\text { immediately }\end{array}$ \\
\hline
\end{tabular}

\section{Results and Discussion}

\subsection{Physical characteristics of sewing machine operators}

Data in the Table 1 revealed the physical characteristics of the women selected for the experiment study. The mean age of sewing machine operators was 36.66 years, mean height, $161 \mathrm{~cm}$, mean and weight was $62.8 \mathrm{~kg}$. The mean BMI of the sewing machine operators was 23.73 that indicated that all the sewing machine operators were having mesomorphic body type indicating good body built. Hence the sewing machine operators were physically fit for the evaluation of further study.

\subsection{Health status of the selected sewing machine operators}

Table 2 Cleary illustrates that the mean body temperature, blood pressure, pulse rate of the sewing machine operators were within the normal range. Aerobic capacity $\left(\mathrm{VO}_{2} \max \right)$ of the sewing machine operators was found to be average and $\mathrm{VO}_{2}$ max. was found high average.

\subsection{Analysis of working posture using RULA}

Analysis of working posture of the sewing machine operators was done using Rapid Upper Limb Assessment technique (RULA). The posture adopted for sewing activity was a sitting with forward bending. Scoring of all the parameters was done to get the overall score. Mean score of wrist and arm, mean score of neck, trunk and leg was taken and then the final scores

Table 1: Physical characteristics of sewing machine operators $(\mathrm{n}=15)$

\begin{tabular}{lc}
\hline Physical characteristics & Mean+S.D. \\
\hline Age (years) & $36.66 \pm 4.47$ \\
Height (cm.) & $1.61 \pm 6.51$ \\
Weight (kg.) & $62.8 \pm 0.07$ \\
BMI & $23.73 \pm 7.03$ \\
\hline
\end{tabular}

Table 2: Health status of the selected sewing machine operators $(\mathrm{n}=15)$

\begin{tabular}{|c|c|c|c|c|}
\hline $\begin{array}{l}\text { Vari- } \\
\text { ables of } \\
\text { health } \\
\text { status }\end{array}$ & $\begin{array}{l}\text { Observed } \\
\text { value } \\
\text { (mean) }\end{array}$ & $\begin{array}{l}\text { Recom- } \\
\text { mended } \\
\text { value }\end{array}$ & $\begin{array}{l}\text { Cat- } \\
\text { egory }\end{array}$ & $\begin{array}{l}\text { Refer- } \\
\text { ence }\end{array}$ \\
\hline $\begin{array}{l}\text { Body } \\
\text { tempera- } \\
\text { ture }\end{array}$ & $98.26 \pm 4.26$ & $98.4^{\circ} \mathrm{F}$ & Normal & $\begin{array}{l}\text { Guyton } \\
\text { and Hall } \\
\text { (2007) }\end{array}$ \\
\hline $\begin{array}{l}\text { Blood } \\
\text { pressure }\end{array}$ & & & & $\begin{array}{l}\text { Guyton } \\
\text { and Hall }\end{array}$ \\
\hline Systolic & $122.13 \pm 1.06$ & $120 \mathrm{~mm} \mathrm{hg}^{-1}$ & Normal & (2007) \\
\hline Diastolic & $80.53 \pm 3.79$ & $80 \mathrm{~mm} \mathrm{hg}^{-1}$ & & \\
\hline $\begin{array}{l}\text { Pulse } \\
\text { rate }\end{array}$ & $77.06 \pm 3.24$ & 70-80 bpm & Normal & $\begin{array}{l}\text { Guyton } \\
\text { and Hall } \\
(2007)\end{array}$ \\
\hline $\begin{array}{l}\mathrm{VO}_{2} \\
\text { max. }\end{array}$ & $30.38667 \pm 2.78$ & & $\begin{array}{l}\text { High } \\
\text { average }\end{array}$ & $\begin{array}{l}\text { Saha } \\
(1978)\end{array}$ \\
\hline
\end{tabular}


were computed.

Table 3 unfolds the analysis of most awkward and frequently used posture during sewing activity i.e., sitting with bending forward. The results revealed that the mean value of wrist and arm score was 4.0 and the mean score for neck, trunk, and leg was worked out to be 6 thus leading to a mean final score of 4 for all the sewing machine operators. This score generates an action level that the sewing machine operators were working in poor posture and there could be a risk of injury to their health from work posture. The reason for this need to be investigated further and change should be implemented soon to prevent injury. No standard deviation was found because all the sewing machine operators were working on floor and adopted same posture while working i.e., the sitting with forward bending. The action category obtained by the analysis of RULA clearly portray that the sewing machine operators

\begin{tabular}{|c|c|c|c|c|c|c|c|c|c|}
\hline Posture & $\begin{array}{l}\text { Posture } \\
\text { score A } \\
\text { (Upper arm+ } \\
\text { lowerarm+ } \\
\text { wrist }+ \\
\text { wrist twist) }\end{array}$ & $\begin{array}{l}\text { Muscle } \\
\text { used } \\
+ \text { Force }\end{array}$ & Score A & $\begin{array}{l}\text { Posture } \\
\text { score B } \\
\text { (Neck, } \\
\text { trunk and } \\
\text { leg score) }\end{array}$ & $\begin{array}{l}\text { Muscle } \\
\text { used }+ \\
\text { Force }\end{array}$ & Score B & $\begin{array}{l}\text { Final } \\
\text { score }\end{array}$ & $\begin{array}{l}\text { Action } \\
\text { category }\end{array}$ & $\begin{array}{l}\text { Further } \\
\text { investi- } \\
\text { gation } \\
\text { re- } \\
\text { quired, } \\
\text { change } \\
\text { soon }\end{array}$ \\
\hline
\end{tabular}

Mean \pm S.D Mean \pm S.D Mean \pm S.D Mean \pm S.D Mean \pm S.D Mean \pm S.D Mean \pm S.D

Sitting $\quad 2+2+3+2=4 \quad 1+2 \quad 5 \quad 3+2+1=3 \quad 1+0 \quad 6 \quad 6 \quad 4 \quad 5$

$1^{*}$ Posture is acceptable if it is not maintained or repeated for long time; $2^{*}$ Further investigation is needed and change may be required; $3^{*}$ Investigation and changes are required soon; $4^{*}$ Investigation and changes are required immediately

were facing discomfort due to poor and awkward posture for prolonged period of time. The postural stress is the main reason for musculoskeletal problems which produces a series of symptoms (Brown, 1976). Hence there is need to correct the posture towards the musculoskeletal problems of sewing machine operators.

A RULA assessment gives a quick and systematic assessment of a postural risk at work. Metamine and Nigel (1993). The final scores obtained from RULA was five which indicated that sewing machine operators were working in poor posture and there could be a risk of injury to their health from work posture, hence investigation and changes are required soon. Louhevaara and suurnakki (1992) reported that working postures causes static load on the musculoskeletal system. Static work results in low efficiency of work. The reduction of the static load caused by poor work posture was one of the main measures for correcting the situation where there was constant increased prevalence of back disorders and musculoskeletal complaints.

(Guangyan et al., 1995) reported that trunk posture was found to be strongly related to the manual aspects of the task, and could be improved by altering the working positions for the arm. Head posture was most influenced by the view of the task/needle and could be improved by improving the visual condition for the task.

\subsection{Angle of deviation while performing sewing activity}

In order to assess the postural stress on female sewing machine operators while performing the sewing activity angle of spine and neck was measured before and during performing the activity. Table 4 highlighted that the normal angle of the cervical region was found to be $187.8^{\circ}$ whereas while performing the sewing activity the angle deviated to $193.93^{\circ}$ indicating deviation of $9.06^{\circ}$ over base. The percent deviation in angle was $4.82 \%$ for the cervical region. Figure 1: revealed that normal angle of lumbar region was found to be $182.02^{\circ}$ and the angle was deviated to $190.85^{\circ}$ during the sewing activity. The deviation in lumbar region was found to be $8.83^{\circ}$ angle of lumbar region was deviated by $4.85 \%$. The ' $t$ ' value was significant at $1 \%$ level of significance for cervical and lumbar region.

Excessive spinal deviation is considered very harmful for the

\begin{tabular}{|c|c|c|c|c|c|}
\hline \multicolumn{6}{|c|}{$\begin{array}{l}\text { Table 4: Angle of deviation while performing sewing activity } \\
(n=15)\end{array}$} \\
\hline Angle & $\begin{array}{c}\text { Angle at } \\
\text { normal } \\
\text { position }\end{array}$ & $\begin{array}{l}\text { Angle at } \\
\text { working }\end{array}$ & $\begin{array}{c}\text { Angle } \\
\text { of } \\
\text { devia- } \\
\text { tion }\end{array}$ & $\begin{array}{c}\text { Per- } \\
\text { cent } \\
\text { in- } \\
\text { crease }\end{array}$ & ' $t$ ' value \\
\hline $\begin{array}{l}\text { Cervi- } \\
\text { cal } \\
\text { region }\end{array}$ & $\begin{array}{c}187.8 \pm \\
3.21\end{array}$ & $\begin{array}{l}193.93 \pm \\
3.97\end{array}$ & 9.06 & 4.82 & $17.11^{* *}$ \\
\hline $\begin{array}{l}\text { Lumbar } \\
\text { region }\end{array}$ & $\begin{array}{c}182.02 \pm \\
2.94\end{array}$ & $\begin{array}{l}190.85 \pm \\
3.32\end{array}$ & 8.83 & 4.85 & $10.35^{* *}$ \\
\hline
\end{tabular}

${ }^{* *}$ Significant at $1 \%$ level 
workers as it exposes them to a risk of development of low back pain (LBP). While performing sewing activity the angle of cervical region was deviated by $4.82 \%$ and deviation in lumbar angle was $4.85 \%$. The ' $t$ ' value for deviation of angle of cervical and lumbar region was statistically significant at $5 \%$ level of significance .The deviation in lumbar and cervical region was found as there was no appropriate workplace in accordance with the anthropometric measurements of the sewing machine operators so they have to bend forward in order to perform the sewing activity. Also the absences of any raised surface beneath the sewing machine lead to deviation in lumbar and cervical region. The deviation in lumbar and cervical region resulted in low back pain, among the sewing machine operators. This low back pain is one of the workplace safety challenge and results in lost work time in the sewing activity. Grandjean (1998) reported that constrained body posture and deviation from neutral posture are the most frequent of static muscular effort.

\section{Conclusion}

The "t" value for the angle of deviation was found highly significant, which resulted into postural discomfort and leads to musculoskeletal disorders among the female sewing machine operators. Therefore, the study concluded that there was an urgent need to correct the working posture of the female sewing machine operators to avoid the incidence of postural discomfort and to enhance the safety, comfort and productivity while working.

\section{Acknowledgment}

The author sincerely acknowledges the ICAR (Indian Council of Agricultural Research) for the financial support in the form of Junior Research Fellowship for her M.Sc. research work. Thanks are also due to the Head and Professor for providing field and laboratory facilities during the course of this investigation.

\section{References}

Atamney, L., Corlett, E., 1993. RULA: A survey method for the investigation of work related upper limb disorder. Applied Ergonomics 24, 91-99.

Brown, J.R., 1976. Manual lifting and related field. An annotated bibliography C.F., Ayoub, M.M., Mittal, A., 1989. Manual material handling, Taylor and Francis, London.

Grandjean, E., 1998. Fitting the task to man: An Ergonomic Approach 183-194.

Guangyan, L., Christine, M., Haslegrave, E., Corlett, N., 1995. Factors affecting posture for machine sewing tasks: The need for changes in sewing machine design. Journal of Applied Ergonomics 26, 231-234.

Herbert, Ryan, N., Pikoski, P., Sjogaard, G., 2006. Shoulder muscle load and muscle fatigue among industrial sewing-machine operators. European Journal of Applied Physiology and Occupational Physiology 67, 467-75.

Kim, S.H., Chung, M.K., 1995. Effect of postural weight and frequency on trunk muscular activity and fatigue during repetitive lifting tasks. Ergonomics 38, 853-863.

Louhevaara, Suurnakki, 1992. A rapid appraisal of occupational work load modified scale of perceived exertion. Ergonomics 37, 485-491.

Metamine, Nigel, 1993. Agricultural work related injury and ill-health and the economic cost. Environmental Science and Pollution 6, 175-182. 